\title{
Plant endemics to Sierra de Gredos (central Spain): taxonomic, distributional, and evolutionary aspects
}

\author{
by \\ Pablo Vargas ${ }^{1} \&$ Bernardo García ${ }^{2}$ \\ ${ }^{1}$ Real Jardín Botánico, CSIC, Plaza de Murillo 2, 28014 Madrid, Spain. vargas@rib.csic.es \\ ${ }^{2}$ Pasaje Prado Sancho 8, 05005 Ávila, Spain. bgarciamun@wanadoo.es
}

\begin{abstract}
Vargas, P. \& García, B. 2008. Plant endemics to Sierra de Gredos (central Spain): taxonomic, distributional, and evolutionary aspects. Anales Jard. Bot. Madrid 65(2): 353-366.

Causes related to a low number of endemics to Sierra de Gredos (central Iberian Peninsula) are poorly understood. Taxonomic, distributional and genetic aspects of the 12 endemic taxa (species and subspecies) are herein discussed. New populations found in the last years provide new chorological reports and taxa to science. As a result, we extend the distribution range of Pseudomisopates rivas-martinezii and describe a new subspecies (Teucrium oxylepis subsp. gredense). Genetic variation was investigated by sequencing the ITS (Internal Transcribed Sequence) region, which is a widespread nuclear DNA region used to detect significant sequence divergence at the species and population levels. At the species level, only eight endemics to this large mountain range (c. 4,800 $\mathrm{km}^{2}$ ) indicates both limited speciation events coupled with their persistence, despite the high species richness of the flora of Sierra de Gredos $(>2,500)$. According to the levels of ITS sequence divergence, significant isolation processes may have predated the Quaternary in Sierra de Gredos to account for divergence of the monotypic genus Pseudomisopates from its closest relatives (Misopates, Acanthorrhinum). Isolation of the other seven endemic species from their closest relatives has been a more recent process, as revealed by the limited ITS sequence variation obtained in this study. At the population level, no net nucleotide substitutions were observed between distant populations of the endemic species: Antirrhinum grosii, Astragalus devesae, Centaurea avilae, Dianthus gredensis, Echinospartum barnadesii, Pseudomisopates rivas-martinezii, Santolina oblongifolia. In contrast, the three populations of Sedum lagascae displayed a relatively high number (4) of nucleotide substitutions. These results, together with limited morphological differentiation, may reflect insufficient population isolation of seven of the eight endemic species of Sierra de Gredos in the Quaternary. Recurrent population contacts or relatively recent range expansion of populations are the two most plausible interpretations in phylogeography of most taxa. Massive extinctions after glacial episodes may have been, in part, responsible for a limited number of endemics and genetic differentiation in
\end{abstract}

\section{Resumen}

Vargas, P. \& García, B. 2008. Plantas endémicas de la Sierra de Gredos (centro de España): aspectos taxonómicos, evolutivos y de distribución. Anales Jard. Bot. Madrid 65(2): 353-366 (en inglés).

Las causas del bajo número de endemismos de la Sierra de Gredos (centro de la Península Ibérica) son poco conocidas. Aspectos taxonómicos, distribucionales y genéticos de los 12 taxones endémicos se discuten en este artículo. Nuevas poblaciones encontradas en los últimos años han resultado ser nuevas citas corológicas y nuevos táxones para la ciencia. En concreto, en este artículo ampliamos la distribución de Pseudomisopates rivas-martinezii y describimos una nueva subespecie (Teucrium oxylepis subsp. gredense). Niveles de variación genética han sido investigados por medio de la secuenciación de la región ITS (del inglés Internal Transcribed Sequence), que es una región de ADN nuclear ampliamente empleada para detectar divergencia genética significativa a nivel de poblaciones. A nivel específico, la presencia de solo ocho especies endémicas de este amplio territorio montañoso (c. $4.800 \mathrm{~km}^{2}$ ) indica escasos eventos de especiación seguidos por procesos de supervivencia de las especies nuevamente formadas, a pesar de la riqueza en especies de la flora de la Sierra de Gredos (>2.500). De acuerdo con los niveles de variación de secuencias ITS, un notable proceso de aislamiento debe haber precedido la divergencia del género monotípico Pseudomisopates de sus parientes más próximos (Misopates, Acanthorrhinum). El aislamiento de las otras siete especies de las especies más próximas ha sido un proceso más reciente tal y como interpretamos por la limitada variación nucleotídica de las secuencias. A nivel poblacional, comparaciones de secuencias ITS realizadas en este estudio no revelan ninguna substitución nucleotídica neta entre poblaciones distantes de los siguientes endemismos: Antirrhinum grosii, Astragalus devesae, Centaurea avilae, Dianthus gredensis, Echinospartum barnadesii, Pseudomisopates rivasmartinezii, Santolina oblongifolia. Por el contrario, las tres poblaciones de Sedum lagascae difirieron en un número (4) relativamente alto de substituciones nucleotídicas. Estos resultados, junto a una escasa diferenciación morfológica, parecen reflejar el insuficiente aislamiento poblacional de siete de las ocho especies endémicas de la Sierra de Gredos durante el Cuaternario. Contactos recurrentes entre las poblaciones o su reciente expansión 
Sierra de Gredos, which contrasts with high levels of endemicity in other areas (hotspots) of the Mediterranean floristic region.

Keywords: conservation, chorology, floristics, genetic variation, ITS sequences, new taxon, phylogeography.

\section{Introduction}

The fact that a low number of species are endemics to central Iberian mountains has been historically discussed by phytogeographers (Boissier, Leresche, Levier, Willkomm, Pau; see Vargas \& Luceño, 1989). Over 2,500 of about 7,000 Iberian species are exclusive to Sierra de Gredos (hereafter Gredos). Although Gredos encompasses c. 4,800 square kilometers (an E-W strip of about $144 \times 42$ $\mathrm{km})$ in a Mediterranean hotspot of biodiversity (Myers \& al., 2000), this territory only harbors 12 endemic species and subspecies (Luceño \& Vargas, 1991a). In contrast, similar numbers of species, but higher number of endemics, are found in mountains of Andalusia and the SE Iberia (Sainz Ollero \& Moreno Saiz, 2002). It has been postulated that long cold episodes in the Quaternary were responsible for extinction of numerous mountain species because rapid temperature decreases hinder migration southwards given the predominant E-W arrangement of many European mountains (Hewitt, 2000) such as Gredos. Restriction of mountain plants in the Quaternary did not necessarily lead to extinction. Plants may have been wiped out in most mountains, but survived depending upon certain conditions and became restricted endemics to a few mountain ranges. Distributional, paleobotanical, and phylogeographic results accumulated in the last decades indicate that some species survived in situ the last European glaciations (Hewitt, 2000), consequently forming part of the endemic element of local floras (Sainz Ollero \& Moreno Saiz, 2002).

Three main mechanisms allow plant populations overcome harsh environments finally dominated by ice sheets: (1) altitudinal, local migration; (2) survival on peripheral mountains; (3) survival on steep areas free of ice by gravity (nunataks) (Stehlik, 2000). These mechanisms may have prevented from extinction of endemic species and intraspecific lineages in the last glaciations. Phylogenetic analyses of seven alpine species distributed in Iberia revealed that most intraspecific (subspecies) differentiation occurred in the Pleistocene (1.75 Ma) (Vargas 2003). In accordance son las interpretaciones más plausibles en filogeografía de la mayor parte de estos táxones endémicos. Asimismo, extinciones masivas durante los episodios glaciares deben haber sido, al menos en parte, responsables de la presencia de un número escaso de endemismos y una baja divergencia genética en un territorio (Sierra de Gredos) que, paradójicamente, está situado en una zona de máxima endemicidad (la región mediterránea).

Palabras clave: conservación, corología, florística, variación genética, secuencias ITS, taxon nuevo, filogeografía.

whith this result, endemic species across Iberian mountains may have been the result of pre-Pleistocene speciation events. The question remains as to whether absence of significant morphological differentiation within the endemic species of Sierra de Gredos reflects limited genetic variation.

Considering a similar number of species distributed across Iberian mountains before Quaternary glaciations, the extinction/survival ratio of endemics may have been higher in Gredos than in the other Iberian mountains. The relatively similar number of species among Iberian mountain ranges (http://www.anthos.es) leads us to hypothesize that extinction followed by Quaternary recolonization from other areas has been predominant in Gredos. This suggests that the three survival mechanisms indicated above primarily failed in Gredos, whereas they played a significant role in some Iberian mountain ranges, such as Cordillera Cantábrica, Pyrenees, Sierra Nevada and the Betic mountains, which harbor higher numbers of mountain endemics (Sainz Ollero \& Moreno Saiz, 2002). In addition, the mountain ranges of the Sistema Central, i. e. Gredos and other local sierras, may have undergone similar biogeographic patterns, given that the number of endemics taxa is somehow proportional to range area (12 in Gredos, 3 in Sierra de Guadarrama, none in Sierra de Ayllón) (Luceño \& Vargas, 1991a).

The present paper addresses four essential aspects in the study of endemic species to Gredos: (1) field prospects of populations, particularly those of endangered species, to determine detailed distribution ranges; (2) taxonomic revision of newly found populations; (3) assessment of ITS sequence variation at the population level; (4) investigation of endangered species to determine the conservation status and potential causes related to restricted distribution of their populations.

\section{Materials and methods}

In the present paper, we define the limits of Gredos as circumscribed by the rivers Corneja, Adaja, 
Alberche, Tiétar, Jerte and Tormes, which encircle six mountain ranges: western (Sierra de Béjar), central (Sierra del Barco and Picos de Gredos) and the eastern massifs -these three constitute the southern, water-shed mountain division-, La Serrota, Sierra de la Paramera and Sierra de Villafranca -these three form the northern mountain range. The northernmost Sierra de Ávila is additionally considered in this study. Gredos consists of primarily granite mountain ranges from low-land valleys $(287 \mathrm{~m})$ to the Almanzor Peak summit (2592 m).

Field prospects were carried out visiting map squares of Gredos by specific habitats of interest. Exhaustive $1 \mathrm{~km}^{2}$ plant search was carried out for the following endangered taxa: Androsace vitaliana subsp. aurelii, Astragalus devesae, Pseudomisopates rivas-martinezii and Saxifraga pentadactylis subsp. almanzorii. All newly found populations were collected and studied using taxonomic approaches. We considered key characters for the taxonomy of each genus. Iberian populations of Androsace vitaliana, $\mathrm{Sa}$ xifraga pentadactylis and Teucrium oxylepis were studied in more detail (including morphometrics of populations from the subspecies already described) given their disjunct distribution.

A particular effort was made to sequence the ITS (Internal Transcribed Spacer) region of the nrDNA from 2-3 distant populations of endemic taxa (Fig. 1) to obtain genetic variation estimates. The ITS region was chosen because it provides molecular variation at the population level in angiosperm species when genetic differentiation is significant (Nieto Feliner \& Rosselló, 2007). Although fine-scale inferences using fingerprinting techniques have yielded higher resolution, congruent variation of ITS sequences has been detected in many studies of mountain species as strong phylogeographical patterns have been retrieved (see Vargas 2003 and references herein). In addition, it is possible to find sequences additivies in ITS sequences, which belong to the multigene family of the nuclear ribosomal DNA, as a result of merging two or more ITS copies in a single plant genome. A total of 15 new ITS sequences of the eight endemic species (Antirrbinum grosii, Astragalus devesae, Centaurea avilae, Dianthus gredensis, Echinospartum barnadesii, Pseudomisopates

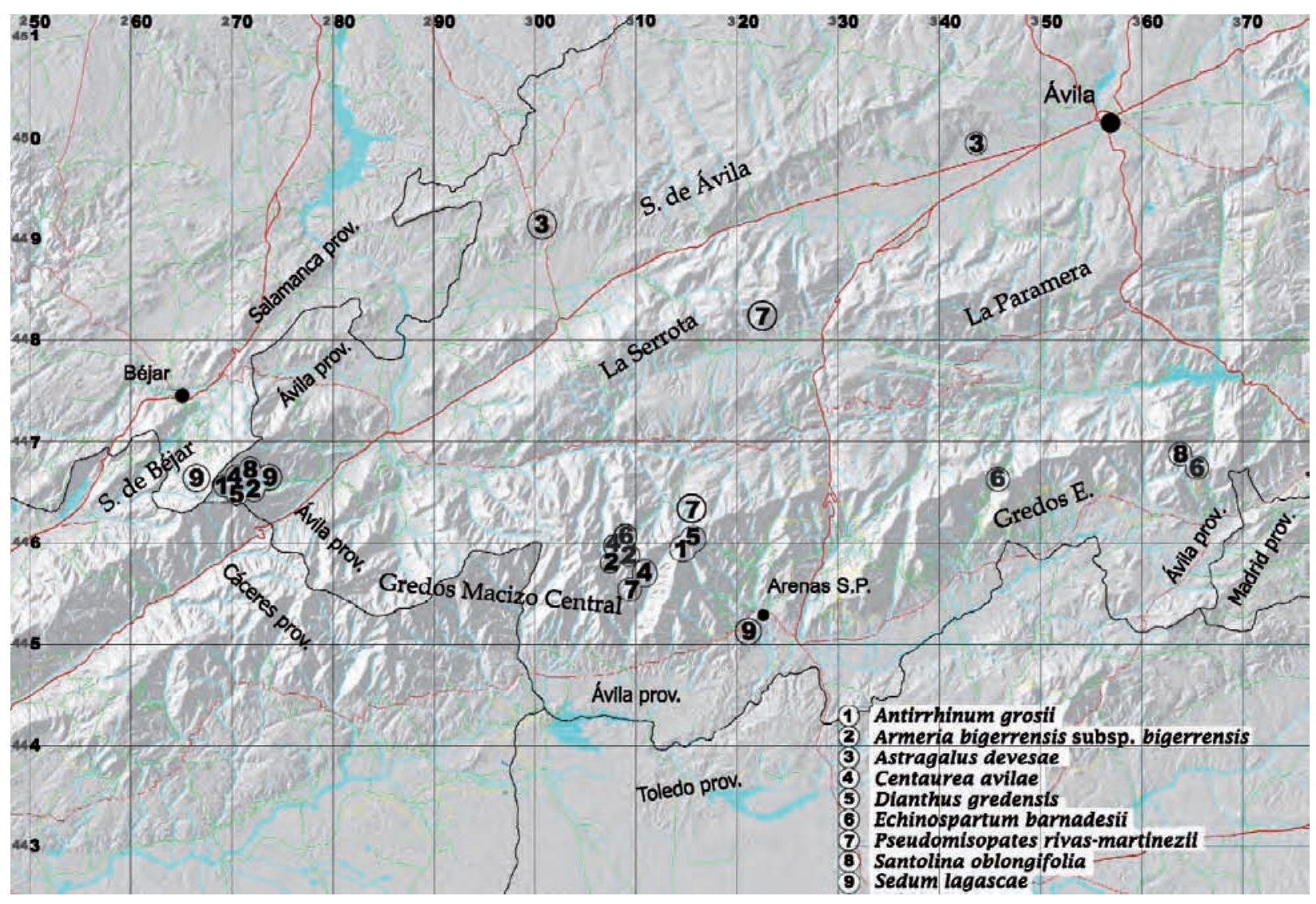

Fig. 1. Localities in Sierra de Gredos from which samples of nine wide-spread taxa of the 12 endemic taxa were collected and ITS sequenced for this and other studies (see also Table 1). Map grid as a result of UTM coordinates. Each square represents $10 \mathrm{~km}{ }^{2}$. 
Table 1. List of studied material from Sierra de Gredos including taxon, geographical unit, locality, voucher, UTM coordinates, altitude and ITS-sequence accession numbers.

\begin{tabular}{|c|c|c|c|}
\hline Taxon (family) & Locality and voucher reference & $\begin{array}{l}\text { UTM coordinates, } \\
\text { altitude }\end{array}$ & $\begin{array}{l}\text { ITS accession } \\
\text { no. }\end{array}$ \\
\hline $\begin{array}{l}1 \text { - Antirrhinum grosii (Antir- } \\
\text { rhinaceae) }\end{array}$ & $\begin{array}{l}\text { Ávila: Gredos, central massif, Guisando, Los Galayos, } \\
\text { Puerta Falsa, leg. B. García }\end{array}$ & 30TUK1459, $2305 \mathrm{~m}$ & Forthcoming \\
\hline $\begin{array}{l}1 \text { - Antirrhinum grosii (Antir- } \\
\text { rhinaceae) }\end{array}$ & $\begin{array}{l}\text { Ávila: Gredos, western massif, Solana de Ávila, garganta } \\
\text { del Trampal, leg. P. Vargas \& al. }\end{array}$ & 30TTK7166, $2010 \mathrm{~m}$ & AY731281 \\
\hline $\begin{array}{l}2 \text { - Armeria bigerrensis (Plum- } \\
\text { baginaceae) }\end{array}$ & $\begin{array}{l}\text { Ávila: Gredos, central massif, Prado de las Pozas; Fuertes } \\
\text { \& al. (2003) }\end{array}$ & & AJ225577 \\
\hline $\begin{array}{l}2 \text { - Armeria bigerrensis (Plum- } \\
\text { baginaceae) }\end{array}$ & $\begin{array}{l}\text { Ávila: Gredos, central massif, Barrera de las Pozas; Fuer- } \\
\text { tes \& al. (2003) }\end{array}$ & & AJ225613 \\
\hline $\begin{array}{l}2 \text { - Armeria bigerrensis (Plum- } \\
\text { baginaceae) }\end{array}$ & $\begin{array}{l}\text { Ávila: Gredos, western massif, El Trampal; Fuertes \& al. } \\
\text { (2003) }\end{array}$ & & AY179765 \\
\hline $\begin{array}{l}3 \text { - Astragalus devesae (Legu- } \\
\text { minosae) }\end{array}$ & $\begin{array}{l}\text { Ávila: Sierra de Ávila, Padiernos, Los Terreros, leg. B. } \\
\text { García }\end{array}$ & & \\
\hline $\begin{array}{l}3 \text { - Astragalus devesae (Legu- } \\
\text { minosae) }\end{array}$ & $\begin{array}{l}\text { Ávila: Sierra de Ávila, Collad } \\
\text { \& al. }\end{array}$ & & Forthcoming \\
\hline $\begin{array}{l}4 \text { - Centaurea avilae (Composi- } \\
\text { tae) }\end{array}$ & $\begin{array}{l}\text { Ávila: Gredos, ce } \\
\text { cuerda del Contac }\end{array}$ & & Forthcoming \\
\hline $\begin{array}{l}4 \text { - Centaurea avilae (Composi- } \\
\text { tae) }\end{array}$ & $\begin{array}{l}\text { Ávila: } \\
\text { Santias }\end{array}$ & & AM114309 \\
\hline $\begin{array}{l}4 \text { - Centaurea avilae (Composi- } \\
\text { tae) }\end{array}$ & $\begin{array}{l}\text { Ávila } \\
\text { Garc }\end{array}$ & 30TTK7066 & Forthcoming \\
\hline $\begin{array}{l}5 \text { - Dianthus gredensis (Caryo- } \\
\text { phyllaceae) }\end{array}$ & a de Gredos, & 30TUK1560, $2160 \mathrm{~m}$ & Forthcoming \\
\hline $\begin{array}{l}5 \text { - Dianthus gredensis (Caryo- } \\
\text { phyllaceae) }\end{array}$ & ae Avila, garganta & 30TTK6965, $2075 \mathrm{~m}$ & Forthcoming \\
\hline $\begin{array}{l}6 \text { - Echinospartum barnadesii } \\
\text { (Leguminosae) }\end{array}$ & aco, Puerto de Ca- & 30TUK6567, $1585 \mathrm{~m}$ & Forthcoming \\
\hline $\begin{array}{l}6 \text { - Echinospartum barnadesii } \\
\text { (Leguminosae) }\end{array}$ & $\begin{array}{l}\text { Ávila: Gredos, eastern massif, Puerto de Mijares, } \\
\text { MAF 160156; Pardo \& al. (2004) }\end{array}$ & $30 T U K 4566$ & AY263624 \\
\hline $\begin{array}{l}6 \text { - Echinospartum barnadesii } \\
\text { (Leguminosae) }\end{array}$ & $\begin{array}{l}\text { Ávila: Gredos, central massif, Prado de las Pozas, } \\
\text { MAF 159291, Pardo \& al. (2004) }\end{array}$ & 30TUK0960 & AF351091 \\
\hline $\begin{array}{l}7 \text { - Pseudomisopates rivas- } \\
\text { martinezii (Antirrhinaceae) }\end{array}$ & Serrota, Cepeda de La Mora, leg. J. Güemes & 30TUK2384 & Forthcoming \\
\hline $\begin{array}{l}7 \text { - Pseudomisopates rivas- } \\
\text { martinezii (Antirrhinaceae) }\end{array}$ & $\begin{array}{l}\text { Ávila: Gredos, central massif, Hoyos del Espino, arroyo } \\
\text { de Los Conventos, leg. B. García }\end{array}$ & 30TUK1461, $1796 \mathrm{~m}$ & AY731265 \\
\hline $\begin{array}{l}7 \text { - Pseudomisopates rivas- } \\
\text { martinezii (Antirrhinaceae) }\end{array}$ & $\begin{array}{l}\text { Ávila: Gredos, central massif, garganta Lóbrega, leg. B. } \\
\text { García }\end{array}$ & 30TUK1057, $1894 \mathrm{~m}$ & Forthcoming \\
\hline $\begin{array}{l}8 \text { - Santolina oblongifolia } \\
\text { (Compositae) }\end{array}$ & $\begin{array}{l}\text { Ávila: Gredos, eastern massif, El Barraco, Puerto de Ca- } \\
\text { sillas, leg. B. García }\end{array}$ & 30TUK6368, $1805 \mathrm{~m}$ & Forthcoming \\
\hline $\begin{array}{l}8 \text { - Santolina oblongifolia } \\
\text { (Compositae) }\end{array}$ & $\begin{array}{l}\text { Ávila: Gredos, western massif, Solana de Ávila, garganta } \\
\text { del Trampal, leg. B. García }\end{array}$ & 30TTK7166, $1655 \mathrm{~m}$ & Forthcoming \\
\hline $\begin{array}{l}9 \text { - Sedum lagascae (Crassula- } \\
\text { ceae) }\end{array}$ & $\begin{array}{l}\text { Ávila: Gredos, central massif, Arenas de San Pedro, Val- } \\
\text { delaosa, leg. B. García }\end{array}$ & 30TTK2144, $480 \mathrm{~m}$ & Forthcoming \\
\hline $\begin{array}{l}9 \text { - Sedum lagascae (Crassula- } \\
\text { ceae) }\end{array}$ & $\begin{array}{l}\text { Ávila: Gredos, western massif, Solana de Ávila, El Chorro, } \\
\text { leg. B. García }\end{array}$ & 30TTK6768, $1868 \mathrm{~m}$ & Forthcoming \\
\hline $\begin{array}{l}9 \text { - Sedum lagascae (Crassula- } \\
\text { ceae) }\end{array}$ & $\begin{array}{l}\text { Salamanca: Gredos, western massif, Candelario, Arroyo } \\
\text { Vicioso, leg. B. García }\end{array}$ & 30TTK6667, $1760 \mathrm{~m}$ & Forthcoming \\
\hline
\end{tabular}


rivas-martinezii, Santolina oblongifolia and Sedum lagascae) were obtained (Tabla 1). Sequencing protocols are summarized in Vargas (2003).

\section{Results and discussion}

Since the first plant records published by Clusius between 1560 and 1565 for central Iberia, plant "hunting" in Gredos has rendered over 2,500 species of vascular plants (Luceño \& Vargas, unpublished), 571 orophilous species (Luceño \& Vargas, 1991b) and eight strictly endemic species (six in Luceño \& Vargas, 1991a). Despite almost five centuries of plant discoveries by numerous botanists (Vargas \& Luceño, 1989), the present paper points to the need for further field search in local sierras or territories where new taxa and floristic records may yet be disclosed. The following distributional, taxonomic, genetic and ecological results, obtained by us in the last eight years, help interpret endemism processes leading to differentiation of 12 species and subspecies in Gredos.

Androsace vitaliana subsp. aurelii Luceño in Anales Jard. Bot. Madrid 56: 165. 1998 (Fig. 2A)

Distribution: one population of around 3150 individuals in the central massif (Sierra del Barco).

Habitat: Rocky and sandy soils between 2160 and $2345 \mathrm{~m}$.

The population of this Primulaceae from Gredos displayed great morphological similarity not only to additional populations of the same mountain range (Sierra de Ayllón), but also to those of other Iberian mountains (Sierra Nevada, Javalambre). Although the population is extremely isolated and endangered (CR status) due to a moderate number of individuals forming a single population (Martínez \& al., 2004a), we did not find significant taxonomic support to discriminate subsp. aurelii from the other Iberian subspecies. Indeed, a morphometric study supports this statement (R. Álvarez \& al., unpublished data). Nucleotide variation of the four subspecies revealed low ITS sequence divergence between A. vitaliana populations in Iberia, which confers a monophyletic group (Vargas, 2003). In fact, only subsp. flosiugorun (NW Iberia) showed sequence divergence (one nucleotide substitution). In contrast, subsp. cinerea (NE Iberia) displayed the most significant morphological character (hairs on the leaf upper part) among Iberian subspecies, but no ITS sequence substitution. New AFLP data and plastid sequences agree with a taxonomic variety rank for these Iberian populations, which reflect limited differentiation (Dixon \& al., unpublished). Ac- cordingly, disjunct distributions of $A$. vitaliana populations in distant Iberian mountain ranges (over 300 $\mathrm{km}$ in same cases) are not the result of ancient isolation processes; rather, recurrent glacial and interglacial migrations in Quaternary phases were hypothesized (Vargas, 2003).

Antirrhinum grosii Font Quer in Bol. Soc. Esp. Hist. Nat. 25: 268. 1925 (Fig. 2B)

Distribution: common in the western and central massifs (from Sierra de Béjar to Los Galayos Peaks).

Habitat: crevices and screes from $1400 \mathrm{~m}$ to summits.

The two ITS samples obtained from the distribution ends of this snapdragon (Antirrhinaceae) rendered no molecular variation. The same double nucleotide peaks readable on both sequence chromatograms agree with previous results in Antirrbinum species, in which hybridization processes were inferred (Vargas \& al., 2004). Multiple copies of the ITS region, including a 1-bp insertion/deletion (indel), detected in the two samples, indicate failure in nucleotide homogenization in $A$. grosii. Low rates of ITS concerted evolution in numerous species suggest that homogenization of ITS copies is a slow process in Antirrbinum. Despite the fact that Antirrbinum grosii resembles both $A$. sempervirens (Pyrenees) and A. pulverulentum (E Iberia), geographical rather than taxonomic proximity appears to have been essential in bringing about hybridization of Antirrbinum in Gredos. Indeed, the same plastid haplotypes have been found in $A$. grosii and $A$. meonanthum from Gredos (Vargas \& al., unpublished data).

Armeria bigerrensis (Pau ex C. Vicioso \& Beltrán) Rivas Mart. subsp. bigerrensis in Anales Inst. Bot. Cavanilles 21: 249. 1964 (Fig. 2C)

Distribution: common in the western and central massifs.

Habitat: crevices, screes and sandy soils above $1000 \mathrm{~m}$.

Three available ITS sequences (Table 1) of this Plumbaginaceae species displayed no change, except for one nucleotide additivity reported for the accession of Sierra de Béjar. Given that the two alternative nucleotides at that position are found in the other two sequences from Gredos and other species from the Iberian Peninsula, failure in sequence homogenization after hybridization appears again to be responsible for a common pattern of reticulation in Armeria (Fuertes Aguilar \& Nieto Feliner, 2003). 
Astragalus devesae Talavera, A. González \& G. López in Lagascalia 21: 194. 1999 (Fig. 2D)

Distribution: two small populations in the eastern (Padiernos) and western (Collado del Mirón) ends of Sierra de Ávila (mountain range to the north of Gredos).

Habitat: calcium-rich (eastern population) and sandy (western population) soils in helm oak wood clearings between 1140 and $1250 \mathrm{~m}$.

This legume species was first found near the northern limits of Gredos (Padiernos, Sierra de Ávila). A second population was recently found by Ángel Amor (University of Salamanca) in Collado del Mirón (personal communication), which suggest the likelihood of finding more scattered populations, and then re-
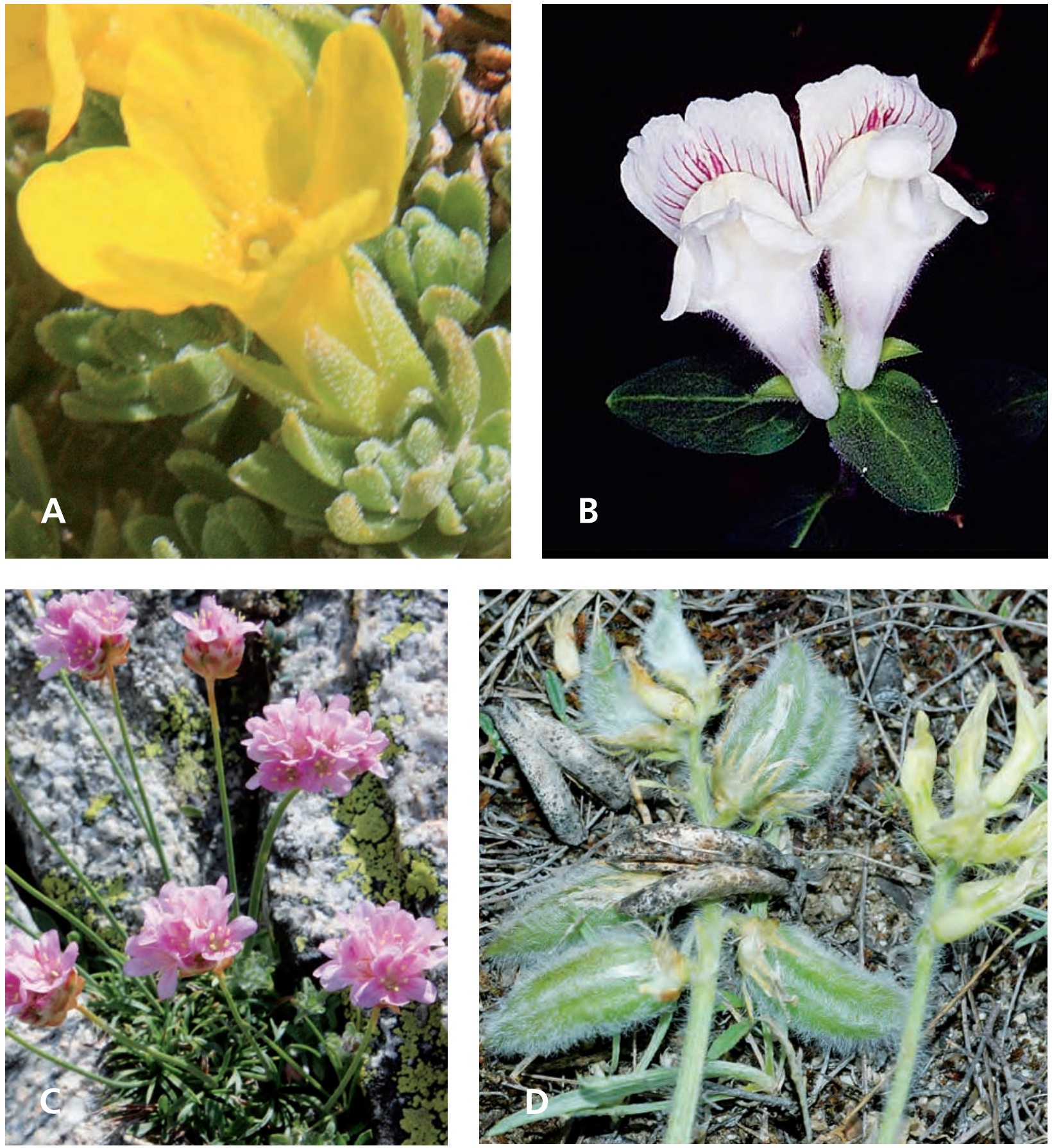

Fig. 2. Plant endemics to Sierra de Gredos: A, Androsace vitaliana subsp. aurelii; B, Antirrhinum grosii; C, Armeria bigerrensis subsp. bigerrensis; $\mathbf{D}$, Astragalus devesae. 
cognition of a more moderate endangered status (Martínez \& al., 2004b). The two reported populations were sampled and rendered no molecular variation. Despite being considered a basophilous endemic in a siliceous territory and the two populations separated by c. $44 \mathrm{~km}$, absence of long-term isolation appears to be responsible for lack of ITS variation.

Centaurea avilae Pau in Butll. Inst. Catalana Hist. Nat. 8: 49. 1908 (Fig. 3A)

Distribution: common in the central massif and scarce in the western massif.

Habitat: rocky and sandy soils, typically between 1000 and $2000 \mathrm{~m}$.

Similar ITS sequences of this Compositae species were observed from samples of three populations, two of them separated at $42 \mathrm{~km}$ (Fig. 1). Molecular variation is based on one ITS additivity in the ITS-1 sequence of the sample from Arenas de San Pedro and one more in the ITS-2 sequence of the sample from Prado de las Pozas (V. Suárez, pers. com.) as retrieved from the GenBank (García-Jacas \& al., 2006). Multiple ITS copies have already been inferred from additivity patterns in some species of Centaurea (Suárez-Santiago \& al., 2007). The two ITS additivities are congruent with the frequent finding of hybrids between C. avilae and C. alba L. throughout Gredos.

Dianthus gredensis Pau ex Caball. in Anales Jard.

Bot. Madrid 5: 512, 521. 1945 (Fig. 3B)

Distribution: common in Gredos and the northernmost Sierra de Ávila.

Habitat: pastures of different types (dry, humid, sandy) and rocky soils over $1000 \mathrm{~m}$.

Again, the same ITS sequence was obtained from two individuals of this pink (Caryophyllaceae) separated by $46 \mathrm{~km}$. A world-wide plastid and nrDNA sequencing study including over 150 Dianthus species rendered a low number of nucleotide substitutions (Valente \& Vargas, unpublished). Indeed, limited variation of ITS sequences was found across the genus. The ITS region appears therefore to be unsuitable to render molecular variation at the population level in Dianthus. In any case, low genetic variation is to be expected across D. gredensis and relatives, given no sequence variation and no unique morphological characters (synapomorphies).

Echinospartum barnadesii (Graells) Rothm. in Bot. Jahrb. Syst. 72: 81.1942 (Fig. 3C)

Distribution: eastern and central massifs.
Habitat: rocky and sandy soils in broom scrub from $1400 \mathrm{~m}$ to summits.

The same ITS sequence was retrieved from three populations of this legume species separated by up to c. $58 \mathrm{~km}$ (Table 1). In addition, low levels of sequence variation are found even in the lineage of the E. barnadesii, where the closest relative (E. ibericum, Salamanca, Navafrías) differs at a single substitution (Pardo \& al., 2004). This result indicates not only low genetic variation between E. barnadesii populations, but also a recent divergence process from the sister species (E. ibericum)

Pseudomisopates rivas-martinezii (Sánchez Mata) Güemes in Anales del Jardín Botánico de Madrid 52: 492-493. 1997 (Fig. 3D)

Distribution: rare in two main population centers in La Serrota and the central massif (Fig. 4).

Habitat: rocky soils on different granite types, including ranker tangle in legume scrub and poor soils of screes and crevices, between 1400 and $2150 \mathrm{~m}$.

The amount of data accumulated from this snapdragon (Antirrhinaceae) since first description (Sánchez Mata, 1988) supports a generic status (Güemes, 1997). Apart from morphological and cytotaxonomic singularities, we consider that genetic differences, as revealed by ITS sequence divergences between the three closely-related Antirrbinaceae genera (Acanthorrbinum-Misopates $4.6 \%$ K-2-p divergence; Misopates-Pseudomisopates $4.4 \%$; Acanthorrbinum-Pseudomisopates $3.9 \%$ ), support a taxonomic rank at the genus level (Vargas \& al., 2004). In fact, ITS sequence divergence estimates between some of the 29 genera of Antirrhinaceae rendered similar values. Pseudomisopates is considered one of the 21 genera endemic to the Iberian Peninsula (Nieto Feliner, 1999) and one of the four endangered ones (Bañares \& al., 2004). It has been suggested that a divergence of Pseudomisopates from the closest genera (Acanthorrbinum, Misopates) about the Miocene-Pliocene limit (Vargas \& al., 2004), provided that rates of nucleotide substitutions parallel those of angiosperms (Richardson \& al., 2001), should be taken into account for particular conservation programs, since the few plants occurring in Gredos are the survivors of an ancient lineage.

Our field prospects, digging out living plants and visiting numerous map squares (Fig. 4), served to disclose the fact that multiple stems (ramets) occurring at the same spot are the result of a single clone (over one-meter stolons were unburied from ramet to ramet; Luceño \& Vargas, unpublished). A population definition is, accordingly, difficult to apply for 

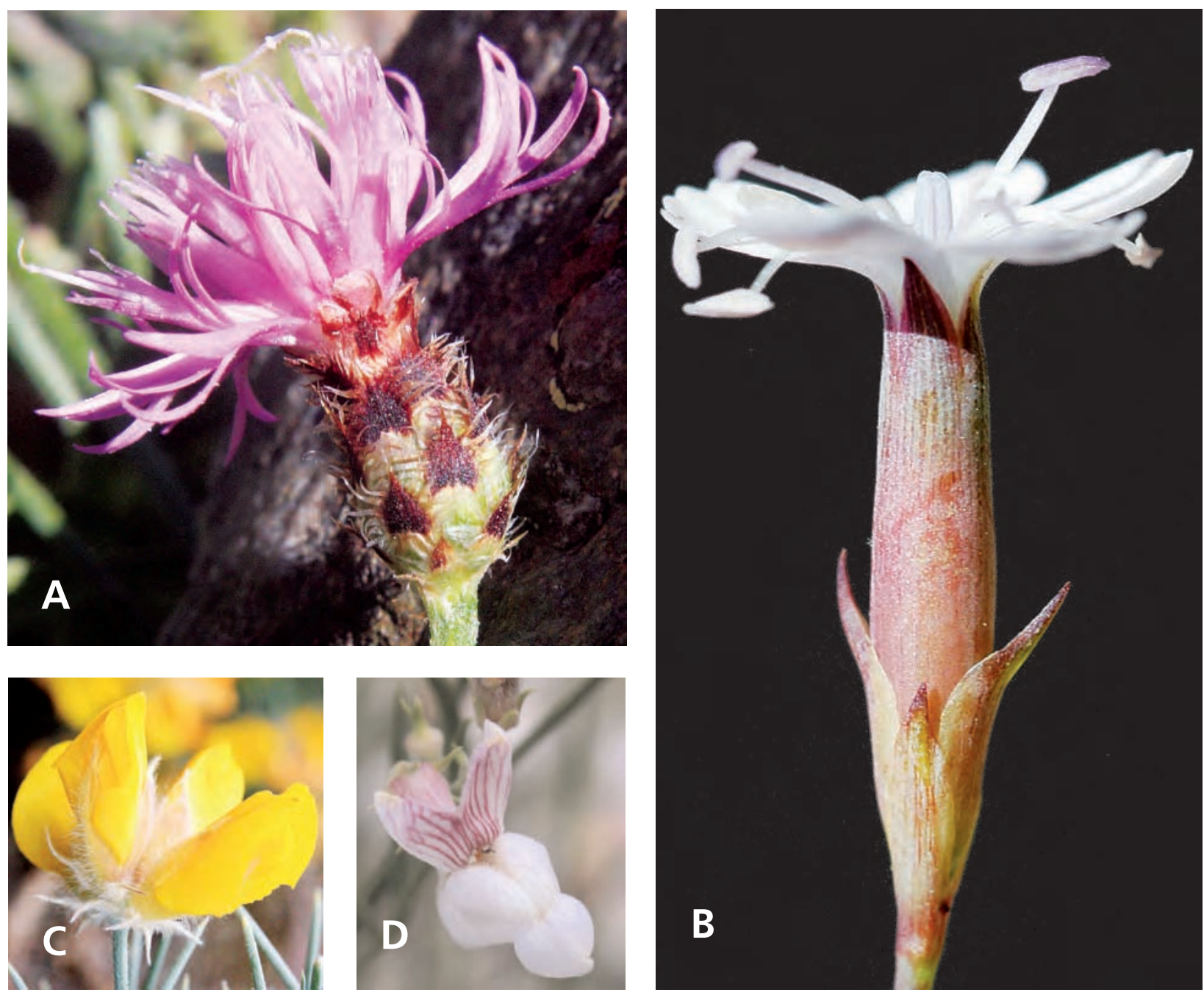

Fig. 3. Plant endemics to Sierra de Gredos: A, Centaurea avilae; B, Dianthus gredensis; C, Echinospartum barnadesii; D, Pseudomisopates rivas-matinezii.

this species. Instead, current studies in progress are based on ramets and genets, given the difficulties of managing a population. After detailed prospects in Gredos by one of us (B. García) from 1997 to 2005 (Fig. 4), two population centers are considered to include populations and groups of ramets scattered in two mountains (La Serrota, northern sierras; and the core of the central massif) (Luceño \& al., 2000; Martínez \& al., 2004c).

Causes related to the low number of Pseudomisopates plants are intriguing. As the plants are scattered in broom scrubs, which is the most common vegetation in Gredos between 1100 and 1900 m, we interpret no habitat limitations. In addition, soil analyses (Luceño $\&$ al., unpublished results) revealed that neither survival nor speciation appears to be related to soil singularity, as suggested by Sánchez Mata (1988). Insect observations in the last five years yielded data on different types of pollinators (Halictus sp., Bombilidae), which rules out pollination problems in the otherwise specialist personate flower of Pseudomisopates. Significant seed and fruit sets (Martínez \& al., 2004c) indicate reproductive success unrelated to the scarcity of $P$. rivas-martinezii populations. Seed germination is, however, remarkably low $(0.06 \%)$ and plant viability appears to be, in part, impeded at this stage (Martínez $\&$ al., 2004c). A preliminary analysis of ISSR (InterSequence Single Repeats) fingerprinting data does not reflect limited genetic variation and therebefore evidence for inbreeding depression. Lack of ITS sequence variation was found in this study from three individuals of the two population centers (separated by $22 \mathrm{~km}$ ). However the fact that there is significant ISSR (Inter-Single Sequence Repeats) variation, 
points to range reduction and fragmentation in more recent times, rather than recent colonization. Further molecular studies (Amat \& Vargas, in progress) may shed further light on historical colonization and isolation processes involved in the rarity of $P$. rivasmartinezii.

Santolina oblongifolia Boiss. in Diagn. Pl. Or. Nov. 3(3): 18. 1856 (Fig. 5A)

Distribution: common in the western, central and eastern massifs.

Habitat: rocky and sandy soils in disturbed broom scrubs from 1200 to $2300 \mathrm{~m}$.

This Compositae species is the Gredos endemic encompassing both a higher territory and occupying a less specific habitat. Although the distance between the two populations we sampled of this species is considerable (c. $96 \mathrm{~km})$, we obtained null ITS nucleotide variation.

Saxifraga pentadactylis subsp. almanzorii P. Vargas in Anales Jard. Bot. Madrid 43(2): 457-458. 1986

(Fig. 5B)
Distribution: relatively common in the core of the central massif (Picos de Gredos).

Habitat: crevices and shady rocky slopes from 1800 to $2500 \mathrm{~m}$.

A subspecific status for this Saxifragaceae endemic has been documented in detail by morphological, artificial crossing experiments, chromosome counts and sequence divergence (Vargas \& Nieto, 1996; Vargas, 2001). Monophyly of the three subspecies (almanzorii, pentadactylis, wilkommiana) and a high number of ITS nucleotide substitutions (6), within S. pentadactylis, indicate single ancestry and relatively old differentiation in mountain ranges of Iberia (Vargas, 2003). Results from different sources of variation and phylogenetic analyses are compatible with an allopatric processes of incomplete speciation in northern (Cordillera Cantábrica, Pyrenees) and central (Sistema Central, Sistema Iberico) Iberian mountains. One exclusive nucleotide substitution supports a morphological differentiation process of recent isolation by predominant selfing in populations of the endemic subsp. almanzorii predating last glaciations (Vargas, 2001). As previously discussed, origin of the infraspe-

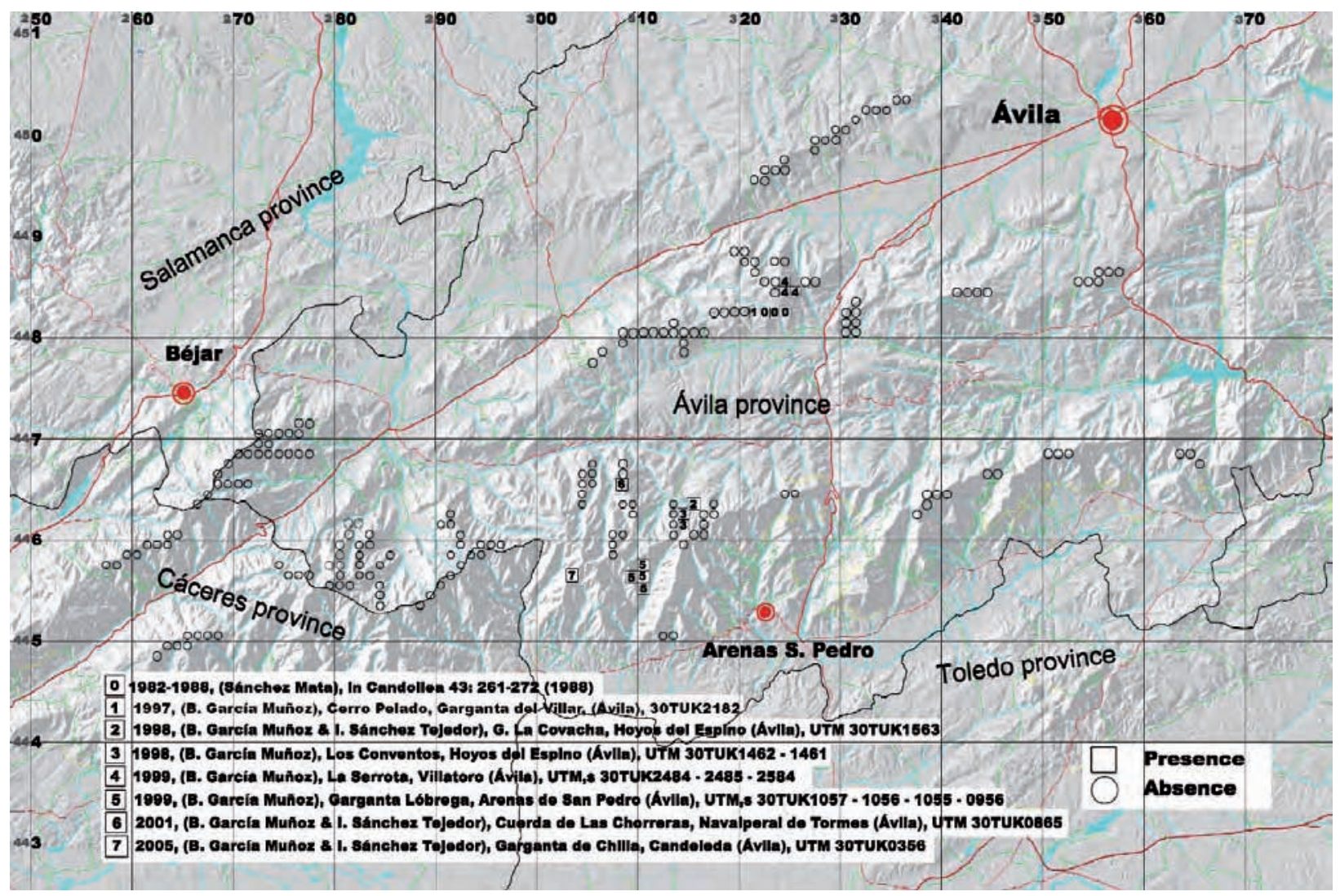

Fig. 4. Presence (squares) and absence (circles) map of Pseudomisopates rivas-martinezii, as revealed by eight prospect campaigns (numbered from 0 to 7). The two symbols (squares and circles) correspond to $1 \mathrm{~km}^{2}$. 
cific taxa (subspecies) of this species is congruent with the differentiation process described for populations of Iberian mountain species between the onset of the Pleistocene and last glaciations (Vargas, 2003).

Sedum lagascae Pau, Not. Bot. Fl. Españ. 6: 53. 1895 (Fig. 5C)

Distribution: common in the central and western massifs.
Habitat: rock faces in wet, dripping crevices and sandy soils between $480 \mathrm{~m}$ and $2100 \mathrm{~m}$.

Although this Crassulaceae species has not been free of nomenclature disagreements (Fernandes, 1982; Laínz, 1985; Velayos \& Castroviejo, 1995; López, 2001), there is no doubt about its specific rank. Conversely to the other endemics, the three populations of this species displayed four different ITS sequences. The two populations from the western massif (Sierra
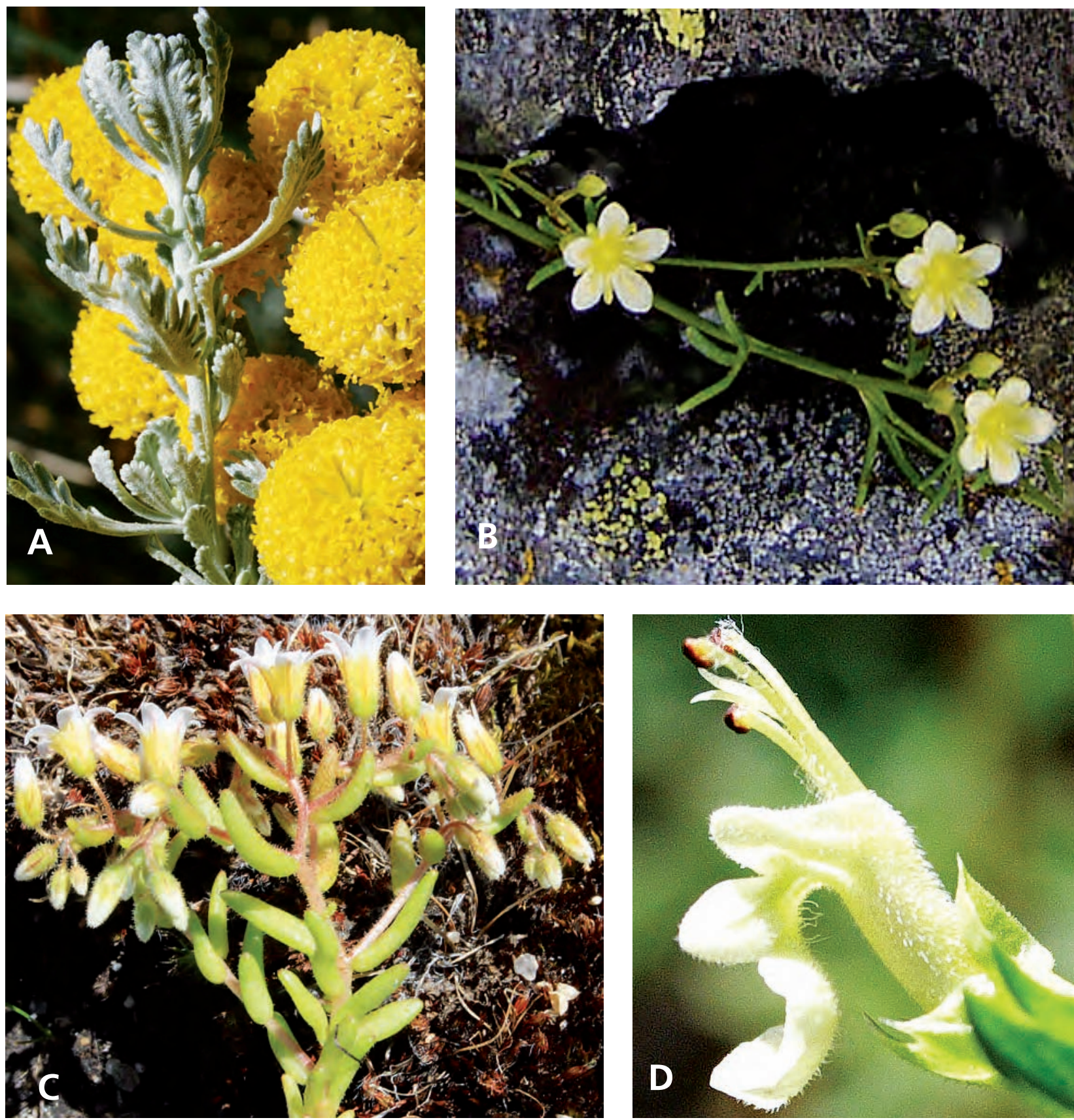

Fig. 5. Plant endemics to Sierra de Gredos: A, Santolia oblongifolia; B, Saxifraga pentadactylis subsp. almanzorii; C, Sedum lagascae; D, Teucrium oxylepis subsp. gredense. 
de Béjar) differed in a single nucleotide substitution ( $\mathrm{T}$ in Candelario; $\mathrm{G}$ in Solana de Ávila). These two populations differed in three substitutions (at sites 79, $530,588)$ to the population from the central massif (Arenas de San Pedro), which are separated by c. $50 \mathrm{~km}$. This result indicates active differentiation patterns in S. lagascae, given that there is not only significant ITS sequence variation between distant populations but also between two populations in the same massif (a distance of c. $10 \mathrm{~km}$ between Sola de Ávila and Candelario).

Teucrium oxylepis subsp. gredense (Muñoz \& P. Vargas, subsp. nov. (Fig $\overline{\mathrm{QD}}$ )

Holotype: SPAIN. Á Boloyo, central massif, Portilla Honda, 30 1950-2020 m, 23-72005, B. García Minoz, N4 753372 . Isotype: ibidem, MA 753371.

Distribution: a बirgle population of c. 150 individuals near Bałago (central massif).

Habitat: crevices and small cracks of granite rocks between 1050 and $2050 \mathrm{~m}$.
Suffrutex; caules procumberes, raciantes, (7)10$25(30) \mathrm{cm}$ longi, pilosi, glan losi. fla ovata vel subtriangularia, subobtusape Acu susi cuneata et saepe asymmetrica, petiolata petzo piloso atque glanduloso-, margine irres Parit dentato-crenulata; bracteae ovato-lanceolatae, Yubtiditer dentatae; inflorescentia plerumque simplex; cox (5)6-7(8) mm longus, pilosus, glandulosus, lok acuminato-aristatis; corolla flavida, tubo 1/3-1/2 orserto.

Subshrub with procumbent, rooting stems, (7) 10-25(30) cm, glandular, hairy; leaves with triangular to ovate blades, acute to almost obtuse tips, cuneate base, often asymmetrical, crenulate margin, with glandular and hairy petiole; bracts finely dentate, with ovate-lanceolate outline; inflorescence usually simple; calyx (5)6-7(8) mm, glandular hairy, with acuminate-aristate lobules; corolla pale yellow, tube $3-4 \mathrm{~mm}, 1 / 3-1 / 2$ calyx exerted (Table 2 ).

Data were taken from the following material

Subsp. oxylepis: MA 98980 (typus), MA 98977 (syntypus), MA 284360, MA 328939, MA 436881, MA

Table 2. Fourteen relevant characters of the 50 morphological features analyzed to distinguish the three subspecies of Teucrium oxylepis.

\begin{tabular}{|c|c|c|c|}
\hline Characters & subsp. oxylepis & subsp. marianum & subsp. gredense \\
\hline Habit & Slender plant & Robust plant & Slender plant \\
\hline Stems length & $20-45 \mathrm{~cm}$ & $25-60 \mathrm{~cm}$ & $(7) 10-25(30) \mathrm{cm}$ \\
\hline Basal leaves size & $10-17 \times 5-11 \mathrm{~mm}$ & $(13) 18-37(40) \times(10) 12-22(25) \mathrm{mm}$ & $10-20(25) \times(5) 7-12(14) \mathrm{mm}$ \\
\hline Bracteoles length & $\begin{array}{l}\text { Shorter than the flower (up to } \\
\qquad 12 \mathrm{~mm} \text { ) }\end{array}$ & $\begin{array}{l}\text { Longer than the flower (up to } \\
\qquad 17 \mathrm{~mm} \text { ) }\end{array}$ & $\begin{array}{l}\text { Similar to the flower (4)5-10(14) } \\
\text { mm }\end{array}$ \\
\hline Inflorescence branching & Branched in 25-30\% & Branched over $50 \%$ & Branched less than $10 \%$ \\
\hline Flower-whorl number & Up to 25 & Up to 35 & Up to 16 \\
\hline Inflorescence length & (12) $15-20 \mathrm{~cm}$ & (8) $10-18(22) \mathrm{cm}$ & $(4) 6-10(12) \mathrm{cm}$ \\
\hline Calyx hairiness & Subglabrous, with short hairs & $\begin{array}{l}\text { Subglabrous, with medium } \\
\text { size hairs }\end{array}$ & $\begin{array}{l}\text { Hairy, with long basal hairs scatte- } \\
\text { red }\end{array}$ \\
\hline Calyx tube length & Up to $6 \mathrm{~mm}$ & Up to $6.5 \mathrm{~mm}$ & Up to $4 \mathrm{~mm}$ \\
\hline Corolla length & Up to $13 \mathrm{~mm}$ & Up to $16 \mathrm{~mm}$ & Up to $11 \mathrm{~mm}$ \\
\hline Nucule size & $1.5 \times 1.0 \mathrm{~mm}$ & $1.5-1.9 \times 1.2-1.3 \mathrm{~mm}$ & $0.8-1.5 \times 0.6-1.3 \mathrm{~mm}$ \\
\hline Nucule indumentum & Glabrous, sessile glands & Glabrous, sessile glands & $\begin{array}{l}\text { Often eglandular trichomes and } \\
\text { sessile glands }\end{array}$ \\
\hline Nucule scar & $\begin{array}{l}\text { c. } 0.5 \mathrm{~mm} \text {, depressed, with } \\
\text { glands }\end{array}$ & $\begin{array}{l}\text { c. } 0.8-1 \mathrm{~mm} \text {, ribbed, with } \\
\text { glands }\end{array}$ & $\begin{array}{l}\text { 0.7-1 mm, slightly depressed, with } \\
\text { glands and seldom scattered trichomes }\end{array}$ \\
\hline Scar/nucule length & $1 / 3$ & c. $1 / 2$ & $1 / 1-1 / 1.5$ \\
\hline
\end{tabular}


174417, MA 580870, MA 179418, MA 620040, MA 210973, MA 632012. These data were complemented with measurements from Font Quer (1924, in Mem. Mus. Ci. Nat. Barcelona, ser. Bot. 1(2): 9).

Subsp. marianum, MA 208300, MA 395155, MA 505831, MA 615247, MA 208886, MA 395191, MA 505847, MA 620041, MA 212646, MA 395206, MA 525828, MA 627165, MA 212647, MA 489342, MA 558029, MA 653895, MA 256817, MA 491141, MA 590748, MA 256818, MA 497740, MA 613155. These data were complemented with measurements from Ruiz de la Torre \& Ruiz del Castillo (1974, in Naturalia Hisp. 1: 42; 1974, in Bol. Est. Central Ecología 3:30).

Subsp. gredense: MA 753372 (holotypus), MA 753371 (isotypus) and more than 100 specimens studied in the field (>50\% of the population).

Two more subspecies of this Labiatae are recognized in Iberia (Castroviejo \& Bayón, 1990): subsp. oxylepis from Sierra de Gádor (Almería) and subsp. marianum, Ruiz de la Torre \& Ruiz del Castillo [in Naturalia Hisp. 1: 42 (1974) [descript.]; Bol. Est. Central Ecología 3(6): 30 (1974)] from Sierra Morena Oriental (Jaén), Montes de Toledo, Sierra de la Higuera (Ciudad Real), Sierra del Castañar (Toledo); Rodríguez Marzal (In Investigación agraria. Sistemas y recursos forestales, ISSN 1131-7965, Vol. 15, N ${ }^{\circ} 1$, 2006, pp. 199-208), Sierra Morena occidental (Badajoz). This new subspecies from Gredos typically resembles subsp. oxylepis, despite being separated by $440 \mathrm{~km}$. Although a SEM analysis did not allow finding discrete characters to discriminate subspecies, as it did to distinguish T. oxylepis and its closest relative (T. afrum, Morocco) (Bayón, 1990; Castroviejo \& Bayón, 1990), certain tendencies are observed (Table 2). As a result of studying 50 features from vegetative and reproductive parts from herbarium specimens (database available upon request to the authors), fourteen morphological differences were found (Table 2) and the most discriminatory characters used in the following key.

\section{KEY TO SUBSPECIES OF TEUCRIUM OXYLEPIS}

1. Robust plants, stems $25-60 \mathrm{~cm}$; basal leaves (13)18-37(40) $\times$ (10) $12-22(25) \mathrm{mm}$.......................... subsp. marianum

- Slender plants, stems (7)10-45 cm; basal leaves 10-20(25) x 5-12(14) $\mathrm{mm}$.................................................... 2

2. Inflorescences up to $20 \mathrm{~cm}$, usually branched in 25-30\%, with up to 25 whorls; nucules only with glands, with its joining scar $1 / 3$ the nucule length ............... subsp. oxylepis

- Inflorescences up to $12 \mathrm{~cm}$, usually branched in less than $10 \%$, with up to 16 whorls; nucules with sessile glands and often scattered trichomes, with its joining scar similar to somewhat shorter than the nucule length ........ subsp. gredense
New populations of T. oxylepis have additionally been found in other Iberian mountains (Sierra de las Nieves, Sierra Nevada) (Cabezudo \& al., 2008), which encourage performing further biometric analysis to determine whether all these populations should be included in three or more subspecies.

\section{Concluding remarks}

Large territories, such as Gredos, contain multiple habitats and pocket refugia to harbor a high number of species and populations, as demonstrated by the discovery of new taxa to science in the last years. A total of six new endemic taxa (see above description protocols) illustrates scientific progress in Gredos in the last two decades. In addition, multiple research groups are contributing with chrorological records to a better understanding of endemic distributions. In particular, 15 new records to Gredos have been published in the Anales del Jardín Botánico de Madrid in the last 30 years. We encourage further botany campaigns in unexplored mountain ranges of Gredos, such as El Jerte and La Vera valleys, Barranco de las Cinco Villas, Sierra de la Paramera, Sierra de Ávila and the eastern massif as a whole, to obtain a more complete flora and knowledge of rare populations.

Relevant molecular variation for the ITS region or any other DNA sequence region would be expected as a result of long term isolation. Accordinly, it is expected that sequence divergence of the ITS region occur in populations of angiosperm species after several hundred thousand years (Richardson \& al., 2001). Using ITS sequence variation, speciation in Mediterranean mountains has been related to preQuaternary isolation, whereas intraspecific differentiation (subspecies) has been related to Quaternary divergence (Vargas, 2003). The fact that no net nucleotide substitution has been found within eight of the nine wide-spread taxa indicates that isolation by both distance and time primarily failed in generating sequence variation. A single exception is constituted by Sedum lagascae, of which three populations displayed three ITS sequences. In agreement with this, few intraspecific taxa are proposed, and sequence identity across populations herein reported lead us to interpret limited allopatric differentiation within Gredos endemics in the Quaternary. Alternatively, sequence identity can be the consequence of the concerted evolution affecting multicopy genes such as this nuclear ribosomal DNA (Nieto Feliner \& Rosselló, 2007), as two or more differentiated populations meet after isolation. Two hypotheses are therefore 
compatible with the limited sequence variation found (except for Sedum lagascae): incomplete isolation because of recurrent population contacts or relatively recent range expansion from restricted areas. Both hypotheses are also compatible with identity of ITS copies, including sequence homogenization after hybridization events.

Massive extinctions after glacial episodes, wiping plants away in Sierra de Gredos may have been, in part, responsible for, not only population decline, but also for extinction of ancient endemics. This may have been more significant in alpine plants than in the extant montane species in which we can classify the endemics to Gredos. In both cases, a single hypothesis to account for the evolutionary history of the orophilous endemics of Gredos is not satisfactory (Vargas, 2003). We interpret that the different numbers of endemics in the Sistema Central of central Iberia (12 in Sierra de Gredos, 3 in Sierra de Guadarrama and none in Sierra de Somosierra-Ayllón) reflect the fact that they may have undergone different evolutionary histories, related not only to the significant differences in land area of each mountain range. On the other hand, a limited number of endemic plants is difficult to relate to the high number of floristic elements recorded in the flora of the Sistema Central. We hypothesize disparate evolutionary patterns in the Sistema Central, given that preliminary studies indicate different patterns of isolation of the endemic populations of Sedum lagascae and Saxifraga pentadactylis subsp. almanzori, whereas recurrent colonization of the few Iberian species has been tested (Purps \& Kadereit, 1998).

The low number of endemics reduces the potential of description of a high number of evolutionary patterns of plants unique to Gredos. In any case, we argue that fine scale molecular studies of plant endemics to Gredos are needed to infer the two phylogeographical patterns herein proposed (recurrent contacts vs. range expansion) in relation to Quaternary episodes.

\section{Ackowledgements}

We thank Emilio Cano for lab assistance, R. Morales and T. Navarro for taxomic comments, Eva Bayón for the SEM photographs, A. Sánchez and M. Laínz for the Latin translation, and Modesto Luceño and an anonymous reviewer for critical comments.

\section{References}

Bañares, A., Blanca, G. Güemes, J., Ortiz, S. \& Moreno, J.C. 2004. Libro Rojo de la Flora Vascular Española. Ministerio de Medio Ambiente. Madrid, Spain.
Bayón, M. I. 1990. Revisión taxonómica del género Teucrium (Labiatae) excl. sect. Polium (Miller) Schreber en la Península Ibérica e Islas Baleares. PhD Dissertation, University of León. León, Spain.

Cabezudo, B., Pérez-LaTorre, A.V., \& Navarro, T. 2008. Sobre la presencia en Málaga de Teucrium oxypelis Font Quer. Acta Botanica Malacitana 33 (en prensa).

Castroviejo, S. \& Bayón, E. 1990. Consideraciones sobre Teucrium sect. Scorodonia (Hill) Schreber. Anales Jardín Botánico de Madrid 47: 512-513.

Fernandes, R. 1982. Sur l'identification de Sedum villosum auct. iber. pro max. parte et de S. villosum var. campanulatum Willk. Boletim da Sociedade Broteriana ser. 2, 57: 129-144

Fuertes Aguilar, J. \& Nieto Feliner, G. 2003. Additive polymorphisms and reticulation in an ITS phylogeny of thrifts (Armeria, Plumbaginaceae). Molecular Phylogenetics and Evolution 28: 430-447.

García Jacas, N., Uysay, T., Romashchenko, K., Suárez-Santiago, V. N., Ertugrul, K. \& Susanna, A. 2006. Centaurea revisited: a molecular survey of the Jacea group. Annals of Botany 98: 741-753.

Güemes, J. 1997. Pseudomisopates (Scrophulariaceae), un nuevo género ibérico. Anales del Jardín Botánico de Madrid 52: 492493.

Hewitt, G. 2000. The genetic legacy of the Quaternary ice ages. Nature 405: 907-913.

Laínz, M. 1985. ¿Mucizonia campanulata (Willk.) R. Fernandes o M. lagascae (Pau) Laínz? Anales de Jardín Botánico de Madrid 42: 248-249.

López, G. 2001. Sobre la correcta aplicación del nombre Sedum lagascae Pau (Crassulaceae). Anales del Jardín Botánico de Madrid 59(1): 148-150.

Luceño, M. \& Vargas, P. 1991a. Guía botánica del Sistema Central español. Pirámide S.A. Madrid, Spain.

Luceño, M. \& Vargas, P. 1991b. Flora vascular orófila del Sistema Central español. Saussurea 21: 151-194.

Luceño, M., López Jiménez, García Muñoz, B., González Canalejo, A. \& Blanco Castro, E. 2000. Aportaciones a la flora de Gredos. IV. Anales del Jardín Botánico de Madrid 57(2): 433 436.

Martínez, J., Valcárcel, V., Fiz, O. \& Vargas, P. 2004a. Androsace vitaliana (L.) Lapeyr. subsp. aurelii Luceño. In: Bañares, A., Blanca, G. Güemes, J., Ortiz, S. \& Moreno, J. C. (eds.), Libro Rojo de la Flora Vascular Española: 879. Ministerio de Medio Ambiente. Madrid, Spain.

Martínez, J., Valcárcel, V., Fiz, O. \& Vargas, P. 2004b. Astragalus devesae Talavera, A. González \& G. López. In: Bañares, A., Blanca, G. Güemes, J., Ortiz, S. \& Moreno, J. C. (eds.), Libro Rojo de la Flora Vascular Española: 132-133. Ministerio de Medio Ambiente. Madrid, Spain.

Martínez, J., Valcárcel, V., Fiz, O. \& Vargas, P. 2004c. Pseudomisopates rivas-martinezii (Sánchez Mata) Güemes. In: Bañares, A., Blanca, G. Güemes, J., Ortiz, S. \& Moreno, J. C. (eds.), Libro Rojo de la Flora Vascular Española: 446-447. Ministerio de Medio Ambiente. Madrid, Spain.

Myers, N., Mittermeier, R.A., Mittermeier, C.G., da Fonseca, G.A.B. \& Kent, J. 2000. Biodiversity hotspots for conservation priorities. Nature 403: 853-858.

Nieto Feliner, G. 1999. Vascular plant distribution in the Iberian Peninsula and the Balearic Islands: current projects. Acta Botanica Fennica 162: 23-33.

Nieto Feliner, G. \& Rosselló, J.A. 2007. Better the devil you know? Guidelines for insightful utilization of nrDNA ITS in species-level evolutionary studies in plants. Molecular Phylogenetics and Evolution 44: 911-919. 
Pardo, C., Cubas, P. \& Tahiri, H. 2004. Molecular phylogeny and systematics of Genista (Leguminosae) and related genera based on nucleotide sequences of nrDNA (ITS region) and cpDNA (trnL-trnF intergenic spacer). Plant Systematics and Evolution 244: 93-119.

Purps, D.M.L. \& Kadereit, J.W. 1998. RAPD evidence for a sister group relationship of the presumed progenitor-derivative species pair Senecio nebrodensis and S. viscosus (Asteraceae). Plant Systematics and Evolution 211: 57-70.

Richardson, J.E., Pennington, R.T., Pennington, T.D. \& Hollingsworth, P.M. 2001. Rapid diversification of a species-rich genus of neotropical rain forest trees. Science 293: 2242-2245.

Sainz Ollero, H. \& Moreno Saiz J. C. 2002. Flora vascular endémica española. In: Pineda, F. D., de Miguel, J. M. \& Casado, M. A. (eds.), La Diversidad Biológica de España. Pearson Educación, S. A. Madrid, Spain.

Sánchez Mata, D. 1988. Misopates rivas-martinezii (Scrophulariaceae), nueva especie del Sistema Central (España). Candollea 43: 261-272.

Stehlik I. 2000. Nunataks and peripheral refugia for alpine plants during quaternary glaciation in the middle part of the Alps. Botanica Helvetica 110(1): 25-30.

Suárez-Santiago, V.N., Salinas, M.J., García-Jacas, N., Soltis, P.S., Soltis, D.E., Blanca, G. 2007. Reticulate evolution in the Acrolophus subgroup (Centaurea L., Compositae) from the western Mediterranean: Origin and diversification of section
Willkommia Blanca. Molecular Phylogenetics and Evolution 43(1): 156-172.

Vargas, P. 2001. Phylogenetic and evolutionary insights in the Saxifraga pentadactylis complex (Saxifragaceae): variation of nrITS sequences. Nordic Journal of Botany 21: 75-82.

Vargas, P. 2003. Molecular evidence for multiple diversification patterns of alpine plants in Mediterranean Europe. Taxon 52: 463-476.

Vargas, P. \& Luceño, M. 1989. Relación de las exploraciones botánicas de la Sierra de Gredos, 1758-1945. Boletín Universitario $7: 31-43$.

Vargas, P. \& Nieto, G. 1996. Artificial hybridization within Saxifraga pentadactylis Lapeyr. (Saxifragaceae). Nordic Journal of Botany 16: 257-266.

Vargas, P., Rosselló, J.A., Oyama, R. \& Güemes, J. 2004. Molecular evidence for naturalness of genera in the tribe Antirrhineae (Scrophulariaceae) and three independent evolutionary lineages from the New World and the Old. Plant Systematics and Evolution 249: 151-172.

Velayos, M. \& Castroviejo, S. 1995. Notas y comentarios sobre el género Sedum L. (Crassulaceae) y su tratamiento para Flora iberica. Anales del Jardín Botánico de Madrid 53: 271-27.

Associate editor: E. Rico Received: 17-XI-2007 Accepted: 18-IX-2008 


\section{Erratum}

Vargas, P. \& García, B. 2008. Plant endemics to Sierra de Gredos (central Spain): taxonomic, distributional, and evolutionary aspects. Anales Jard. Bot. Madrid 65(2): 353-366.

Teucrium oxylepis subsp. gredense B. García \& P. Vargas, subsp. nov. (Fig. 5D)

Holotype: SPAIN. Ávila: Bohoyo, central massif, Portilla Honda, 30TTK9559, 1950-2020 m, 23-72005, B. García Muñoz, MA 753372. Isotype: ibidem, MA 753371.

Distribution: a single population of c. 150 individuals near Bohoyo (central massif).
Habitat: crevices and small cracks of granite rocks between 1950 and $2050 \mathrm{~m}$.

Suffrutex; caules procumbentes, radicantes, (7)10$25(30) \mathrm{cm}$ longi, pilosi, glandulosi; folia ovata vel subtriangularia, subobtusa vel acuta, basi cuneata et saepe asymmetrica, petiolata - petiolo piloso atque glanduloso-, margine irregulariter dentato-crenulata; bracteae ovato-lanceolatae, subtiliter dentatae; inflorescentia plerumque simplex; calyx (5)6-7(8) mm longus, pilosus, glandulosus, lobulis acuminato-aristatis; corolla flavida, tubo 1/3-1/2 exserto.

Table 1. List of studied material from Sierra de Gredos including taxon, geographical unit, locality, voucher, UTM coordinates, altitude and ITS-sequence accession numbers.

\begin{tabular}{|c|c|c|c|}
\hline Taxon (family) & Locality and voucher reference & $\begin{array}{l}\text { UTM coordinates, } \\
\text { altitude }\end{array}$ & $\begin{array}{l}\text { ITS accession } \\
\text { no. }\end{array}$ \\
\hline $\begin{array}{l}1 \text { - Antirrhinum grosii (Antirrhi- } \\
\text { naceae) }\end{array}$ & $\begin{array}{l}\text { Ávila: Gredos, central massif, Guisando, Los Galayos, } \\
\text { Puerta Falsa, leg. B. García }\end{array}$ & 30TUK1459, 2305 m & FJ897728 \\
\hline $\begin{array}{l}1 \text { - Antirrhinum grosii (Antirrhi- } \\
\text { naceae) }\end{array}$ & $\begin{array}{l}\text { Ávila: Gredos, western massif, Solana de Ávila, garganta } \\
\text { del Trampal, leg. P. Vargas \& al. }\end{array}$ & 30TTK7166, $2010 \mathrm{~m}$ & AY731281 \\
\hline $\begin{array}{l}2 \text { - Armeria bigerrensis (Plum- } \\
\text { baginaceae) }\end{array}$ & $\begin{array}{l}\text { Ávila: Gredos, central massif, Prado de las Pozas; Fuertes } \\
\text { \& al. (2003) }\end{array}$ & 30TUK0960 & AJ225577 \\
\hline $\begin{array}{l}2 \text { - Armeria bigerrensis (Plum- } \\
\text { baginaceae) }\end{array}$ & $\begin{array}{l}\text { Ávila: Gredos, central massif, Barrera de las Pozas; Fuer- } \\
\text { tes \& al. (2003) }\end{array}$ & 30TUK0859 & AJ225613 \\
\hline $\begin{array}{l}2 \text { - Armeria bigerrensis (Plum- } \\
\text { baginaceae) }\end{array}$ & $\begin{array}{l}\text { Ávila: Gredos, western massif, El Trampal; Fuertes \& al. } \\
\text { (2003) }\end{array}$ & 30TUK1056 & AY179765 \\
\hline $\begin{array}{l}3 \text { - Astragalus devesae (Legu- } \\
\text { minosae) }\end{array}$ & $\begin{array}{l}\text { Ávila: Sierra de Ávila, Padiernos, Los Terreros, leg. B. } \\
\text { García }\end{array}$ & 30TUK4499, $1140 \mathrm{~m}$ & FJ897729 \\
\hline $\begin{array}{l}3 \text { - Astragalus devesae (Legu- } \\
\text { minosae) }\end{array}$ & $\begin{array}{l}\text { Ávila: Sierra de Ávila, Collado del Mirón, leg. P. Vargas } \\
\text { \& al. }\end{array}$ & 30TUK0192, $1200 \mathrm{~m}$ & FJ897730 \\
\hline $\begin{array}{l}4 \text { - Centaurea avilae (Composi- } \\
\text { tae) }\end{array}$ & $\begin{array}{l}\text { Ávila: Gredos, central massif, Arenas de San Pedro, cuer- } \\
\text { da del Contadero, leg. B. García }\end{array}$ & 30TUK1056, $1570 \mathrm{~m}$ & FJ897731 \\
\hline $\begin{array}{l}4 \text { - Centaurea avilae (Composi- } \\
\text { tae) }\end{array}$ & $\begin{array}{l}\text { Ávila: Gredos, central massif, Prado de las Pozas; Suárez- } \\
\text { Santiago \& al. (2007) }\end{array}$ & 30TUK0960 & AM114309 \\
\hline $\begin{array}{l}4 \text { - Centaurea avilae (Composi- } \\
\text { tae) }\end{array}$ & $\begin{array}{l}\text { Ávila: Gredos, western massif, Solana de Béjar, leg. B. } \\
\text { García }\end{array}$ & 30TTK7066 & FJ897732 \\
\hline $\begin{array}{l}5 \text { - Dianthus gredensis (Caryo- } \\
\text { phyllaceae) }\end{array}$ & $\begin{array}{l}\text { Ávila: Gredos, central massif, Navarredonda de Gredos, } \\
\text { Las Tarayuelas, leg. B. García }\end{array}$ & 30TUK1560, $2160 \mathrm{~m}$ & CQ148876 \\
\hline
\end{tabular}


Table 1. (Continuation).

\begin{tabular}{|c|c|c|c|}
\hline Taxon (family) & Locality and voucher reference & $\begin{array}{l}\text { UTM coordinates, } \\
\text { altitude }\end{array}$ & $\begin{array}{l}\text { ITS accession } \\
\text { no. }\end{array}$ \\
\hline $\begin{array}{l}5 \text { - Dianthus gredensis (Caryo- } \\
\text { phyllaceae) }\end{array}$ & $\begin{array}{l}\text { Ávila: Gredos, western massif, Solana de Ávila, garganta } \\
\text { del Trampal, leg. B. García }\end{array}$ & 30TTK6965, $2075 \mathrm{~m}$ & CQ148877 \\
\hline $\begin{array}{l}6 \text { - Echinospartum barnadesii } \\
\text { (Leguminosae) }\end{array}$ & $\begin{array}{l}\text { Ávila: Gredos, eastern massif, El Barraco, Puerto de Casi- } \\
\text { Ilas, leg. B. García }\end{array}$ & 30TUK6567, $1585 \mathrm{~m}$ & FJ897733 \\
\hline $\begin{array}{l}6 \text { - Echinospartum barnadesii } \\
\text { (Leguminosae) }\end{array}$ & $\begin{array}{l}\text { Ávila: Gredos, eastern massif, Puerto de Mijares, } \\
\text { MAF 160156; Pardo \& al. (2004) }\end{array}$ & 30TUK4566 & AY263624 \\
\hline $\begin{array}{l}6 \text { - Echinospartum barnadesii } \\
\text { (Leguminosae) }\end{array}$ & $\begin{array}{l}\text { Ávila: Gredos, central massif, Prado de las Pozas, } \\
\text { MAF 159291; Pardo \& al. (2004) }\end{array}$ & 30TUK0960 & AF351091 \\
\hline $\begin{array}{l}7 \text { - Pseudomisopates rivas- } \\
\text { martinezii (Antirrhinaceae) }\end{array}$ & Ávila: La Serrota, Cepeda de La Mora, leg. J. Güemes & $30 T U K 2384$ & FJ897734 \\
\hline $\begin{array}{l}7 \text { - Pseudomisopates rivas- } \\
\text { martinezii (Antirrhinaceae) }\end{array}$ & $\begin{array}{l}\text { Ávila: Gredos, central massif, Hoyos del Espino, arroyo de } \\
\text { Los Conventos, leg. B. García }\end{array}$ & 30TUK1461, $1796 \mathrm{~m}$ & AY731265 \\
\hline $\begin{array}{l}7 \text { - Pseudomisopates rivas- } \\
\text { martinezii (Antirrhinaceae) }\end{array}$ & $\begin{array}{l}\text { Ávila: Gredos, central massif, garganta Lóbrega, leg. B. } \\
\text { García }\end{array}$ & 30TUK1057, $1894 \mathrm{~m}$ & FJ897735 \\
\hline $\begin{array}{l}8 \text { - Santolina oblongifolia } \\
\text { (Compositae) }\end{array}$ & $\begin{array}{l}\text { Ávila: Gredos, eastern massif, El Barraco, Puerto de Casi- } \\
\text { llas, leg. B. García }\end{array}$ & 30TUK6368, $1805 \mathrm{~m}$ & FJ897736 \\
\hline $\begin{array}{l}8 \text { - Santolina oblongifolia } \\
\text { (Compositae) }\end{array}$ & $\begin{array}{l}\text { Ávila: Gredos, western massif, Solana de Ávila, garganta } \\
\text { del Trampal, leg. B. García }\end{array}$ & 30TTK7166, $1655 \mathrm{~m}$ & FJ897737 \\
\hline $\begin{array}{l}9 \text { - Sedum lagascae (Crassula- } \\
\text { ceae) }\end{array}$ & $\begin{array}{l}\text { Ávila: Gredos, central massif, Arenas de San Pedro, Val- } \\
\text { delaosa, leg. B. García }\end{array}$ & 30TTK2144, $480 \mathrm{~m}$ & FJ897738 \\
\hline $\begin{array}{l}9 \text { - Sedum lagascae (Crassula- } \\
\text { ceae) }\end{array}$ & $\begin{array}{l}\text { Ávila: Gredos, western massif, Solana de Ávila, El Chorro, } \\
\text { leg. B. García }\end{array}$ & 30TTK6768, $1868 \mathrm{~m}$ & FJ897739 \\
\hline $\begin{array}{l}9 \text { - Sedum lagascae (Crassula- } \\
\text { ceae) }\end{array}$ & $\begin{array}{l}\text { Salamanca: Gredos, western massif, Candelario, Arroyo } \\
\text { Vicioso, leg. B. García }\end{array}$ & 30TTK6667, $1760 \mathrm{~m}$ & FJ897740 \\
\hline
\end{tabular}

Pablo Vargas \& Bernardo García 